\title{
The Esterases of Mortierella ramanniana in Relation to Taxonomy
}

\author{
By J. F. PEBERDY AND MYFANWY TURNER \\ Department of Botany, University of Nottingham
}

(Accepted for publication 16 October 1967)

\begin{abstract}
SUMMARY
The esterase profiles of 9 strains of Mortierella ramanniana grown on glucose and olive-oil media were determined by starch-gel electrophoresis. The enzymes produced on the oil medium were in most instances produced also on the glucose medium, but on the latter some additional esterase components were produced. The esterase patterns of the different strains varied widely; only one esterase was common to all strains grown on glucose medium, and a second esterase was common to all grown on the olive-oil medium. The data available do not suggest that esterase profiles are of taxonomic significance for these fungi.
\end{abstract}

\section{INTRODUCTION}

Previous studies of some species of the genus Mortierella showed that the synthesis of fat and the utilization of extracellular fats were important aspects of their metabolism (Chesters \& Peberdy, 1965). This indicated that esterases (carboxylic ester hydrolases, E.C. 3.I.r.) are important enzyme systems in these fungi. Several workers have shown that gel electrophoresis is a suitable technique for studying esterases and in many cases the system has been found to consist of a group of molecular species, not a single enzyme (Aranson \& Pantelouris, 1966; Robinson, 1966). Gel electrophoresis has been used as a taxonomic aid by several workers. Protein patterns were found useful with various fungi (Chang, Srb \& Steward, 1962; Clare, 1963; Durbin, I966) and actinomycetes (Gottlieb \& Hepden, 1966). Esterase patterns have also been found to be a useful taxonomic criterion for bacteria (Norris, 1964; Cann \& Willox, 1965; Robinson, 1966). In view of the possible importance of esterase systems in Mortierella it was thought to be of interest to extend the electrophoretic study to these fungi.

Characteristics of primary importance in fungal taxonomy include measurements of spores and spore-bearing structures, as well as characters of the vegetative mycelium and the colour of mycelium and spores. In the Mucorales the mode of branching of the sporangiophores is important, and the production of characteristic resting bodies may have secondary significance. The group of species typified by Mortierella isabellina Oudemans \& Koning, in which $M$. ramanniana can be placed, differs markedly in morphology from the rest of the genus. Within this group, 5 major species can be distinguished on morphological characters (Turner, 1963) but the distinction is not always clear-cut. Any biochemical characters which might help to define these species, or to separate this group from the rest of the genus, could be of value; but it is neces- 
sary first to ascertain whether the character under consideration is constant within a given species, and whether any variations show sufficient correlation with morphological variation to make comparison with other species of value.

\section{METHODS}

The organisms. Nine strains of Mortierella ramanniana (Moëller) Linnemann were used (designated 20, 23, 29, I 19, 138, 163, 187, 212, 213). Cultures were maintained on potato glucose agar (Oxoid), and for morphological examination were grown at room temperature (about $20^{\circ}$ ) for 5-7 days on soil extract agar ( $\mathrm{pH} \mathrm{6.0)} \mathrm{containing} \mathrm{(g./1.):}$ glucose, $\mathrm{I} \cdot 0 ; \mathrm{KH}_{2} \mathrm{PO}_{4}, 0.2$; yeast extract (Oxoid), $0 . \mathrm{I}$. All measurements were made on unstained material, freshly mounted in $0.9 \% \mathrm{NaCl}$. Spores were measured by the camera-lucida method.

Composition of media for esterase production. The basal medium contained (g./1.): $\left(\mathrm{NH}_{4}\right)_{2} \mathrm{HPO}_{4}, \mathrm{I} \cdot 0 ; \mathrm{KCl}, 0.2 ; \mathrm{MgSO}_{4} \cdot 7 \mathrm{H}_{2} \mathrm{O}, 0.2$; yeast extract (Oxoid), I0.0. To this solution glucose $20 \mathrm{~g}$./1., or olive oil B.P. (Boots Pure Drug Co. Ltd.) $20 \mathrm{ml}$./1. were added as carbon source. The medium was adjusted to $\mathrm{pH} 6.5$ before autoclaving at $108^{\circ}$ for $30 \mathrm{~min}$. The olive oil was sterilized separately by heating at $160^{\circ}$ for $2 \mathrm{hr}$ and added aseptically to the culture medium.

Inoculation and incubation. Cultures were grown in squat I 1 . conical flasks containing $300 \mathrm{ml}$. medium, inoculated with $5 \mathrm{ml}$. of spore suspension prepared from 7day cultures on potato glucose agar. The flasks were incubated at $25^{\circ}$, on a reciprocal shaker. After 5 days, cultures were harvested by filtration and the mycelial pads thoroughly washed with cold distilled water before extraction of enzymes.

Preparation of mycelial extracts. The washed mycelium was ground at $4-5^{\circ}$, in a pre-cooled mortar, with an equal quantity of acid-washed sand, for about Io min. In early preparations, about $3 \mathrm{ml}$. cold Mcllvaine buffer ( $\mathrm{pH} \mathrm{6.4)} \mathrm{was} \mathrm{added} \mathrm{during}$ the final stages of grinding; later the buffer was replaced by cold distilled water with no detrimental effect. Sand and mycelial fragments were removed by centrifugation at $2500 \mathrm{~g}$ for Io min. The supernatant fluid was distributed into small tubes and stored at $-20^{\circ}$. Samples have been stored for up to 6 months, during which time some of the component enzymes deteriorated until finally they became inactive.

Electrophoresis. The mycelium homogenates were analysed by the starch-gel technique of Smithies (1955) with hydrolysed starch (Connaught Medical Research Laboratories) and the discontinuous buffer system of Poulik (I957) as modified by Baillie \& Norris (1963). Electrophoresis was done at room temperature (about $20^{\circ}$ ) at constant voltage (7-10 V./cm. gel). The initial current applied to the gels was $25 \mathrm{~mA}$. The buffer front was allowed to run $10 \mathrm{~cm}$. from the starting line towards the anode. In some gels the brown line, which marked the position of the buffer front, was not always clear. This difficulty was overcome by using bromothymol blue as a marker dye, which ran with the buffer front. Horse serum was used as a standard with all gels.

Detection of esterases. On completion of electrophoresis the gels were sliced into 4 layers, $\mathrm{I} \cdot 5 \mathrm{~mm}$. thick. The middle two slices were stained for esterases by the method of Lawrence, Melnick \& Weimer (1960). The gel slices were flooded with a freshly prepared solution of tris maleate buffer (0.I M, pH 6.4) $200 \mathrm{ml}$.; I \% (w/v) $\alpha$-napthyl acetate in $50 \%(\mathrm{v} / \mathrm{v}$ ) acetone in water, $8 \mathrm{ml}$.; fast blue salt B (Gurr) $0 . \mathrm{I} \mathrm{g}$. The presence of esterases was indicated by the appearance of red bands after $\mathrm{I} \mathrm{hr}$ at room temperature $\left(20^{\circ}\right)$. 
Photography. The stained gels were photographed by reflected light, with Kodalith ortho type 3 film and D 19B or D 163 developer.

\section{RESULTS}

Esterase preparations were obtained from 3 cultures of each strain on each medium. The positions of the esterase bands were measured and the $E_{F}$ values given have been corrected to a horse serum standard of 0.68 .

Data of the electrophoretic analyses is given in Tables $I$ and 2 and the esterase profiles are presented graphically after the manner of Gottlieb \& Hepden (I966) in Fig. I. Measurements of morphological structures are summarized in Table 3.

These data indicate that there were 15 different components in the esterase systems of the strains examined; the maximum number for any I strain was Io, in strain 213 grown on olive-oil medium. Thus the esterase systems in these fungi are also multimolecular systems. It is sometimes difficult to decide the correct location of a band, e.g. strain 20 on both media has a component with an $E_{F}$ value in the range 0.840.88 , which has been designated band $l$, but may well be identical with band $k$ produced by other strains. The $E_{F}$ values for any one band in a given strain may also vary, e.g. band $k$ in strain 29 on glucose medium. It is intended to submit these and additional data to statistical treatment and so give a more precise picture of the profiles.

The effect of the medium on the esterase system of these fungi was not very marked. In some strains more enzymes were produced by the cultures when grown on glucose medium than on oil medium. The esterases present in the mycelium produced on oil medium were almost always produced also on the glucose medium.

The esterase patterns of the nine strains showed little resemblance, though 8 of them had at least I band in common (band h, mean $E_{F} 0.75$, on glucose medium, and band $\mathrm{j}$, mean $E_{F} 0.80$, on oil medium). Strain 163 was unique in showing 3 components, 3 of which were broad bands about $\mathrm{I} \mathrm{cm}$. wide. Attempts to analyse the preparations from this strain by vertical starch-gel electrophoresis, in the hope of separating these broad bands into further components, were unsuccessful.

\section{DISCUSSION}

Expression of the esterase profile in terms of $E_{F}$ values has obvious advantages over a purely qualitative description. Chang et al. (1962) and Gottlieb \& Hepden (1966) published quantitative data ( $R_{F}$ or $E_{F}$ values) but only the latter give evidence of variation in the position of particular protein bands in the gels. In comparison with the data of Gottlieb \& Hepden our results show a little more variation. This might well be a reflexion of the different electrophoresis methods used. One serious problem with the horizontal starch-gel method is the frequent uneven running of the buffer front; this can make measurements difficult particularly when the brown line marking the buffer front in the gel is not clearly visible.

As yet we have no evidence of the role of the esterases produced by these fungi. In cultures grown on glucose medium the enzymes may function at a later stage of development if the exogenous energy source is depleted and the intracellular fat utilized. Whether these same enzymes are used in the breakdown of extracellular oils when supplied as a carbon source is also unknown. There is no doubt that the olive oil is 


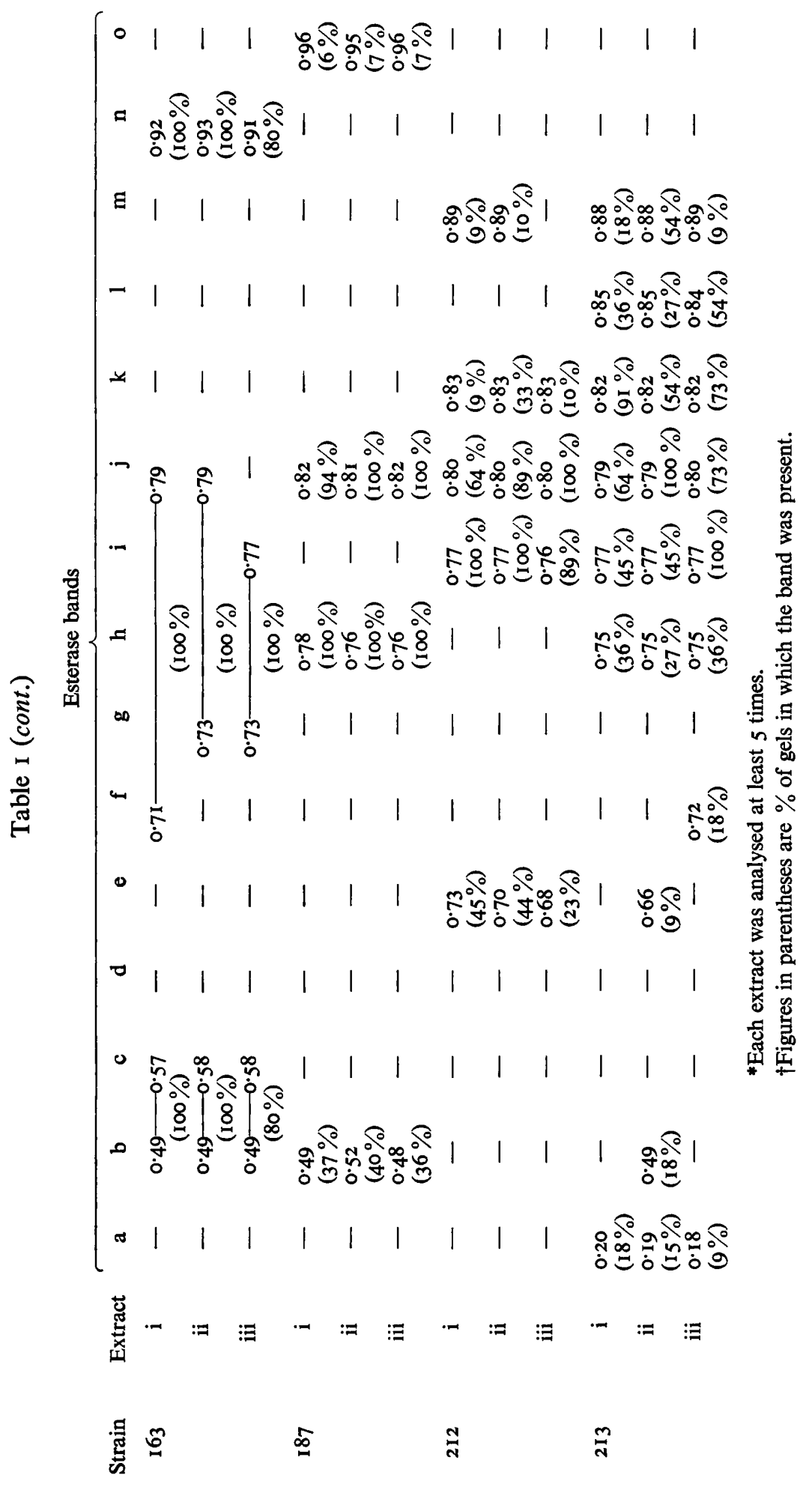


308

J. F. PEBERDY AND M. TURNER

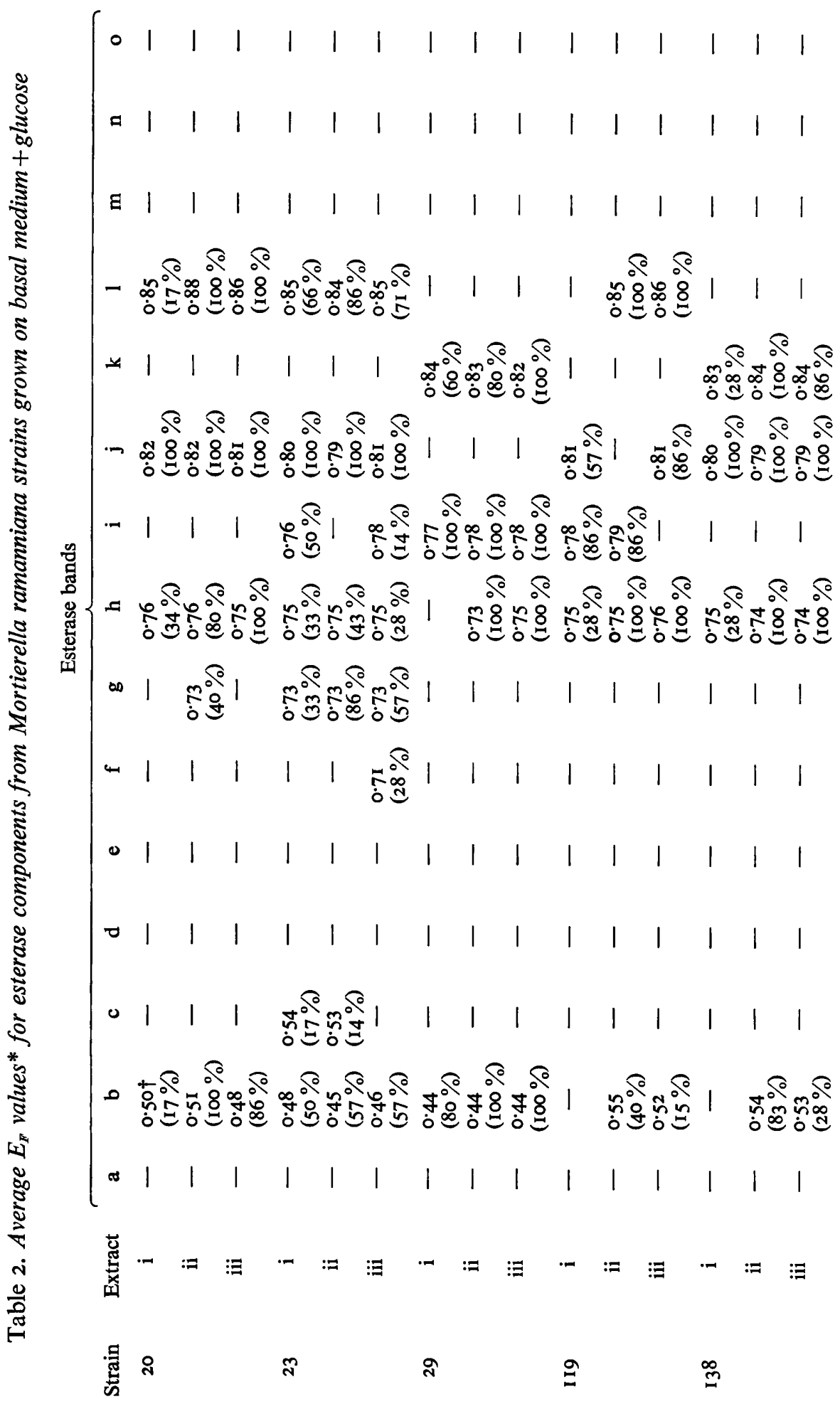




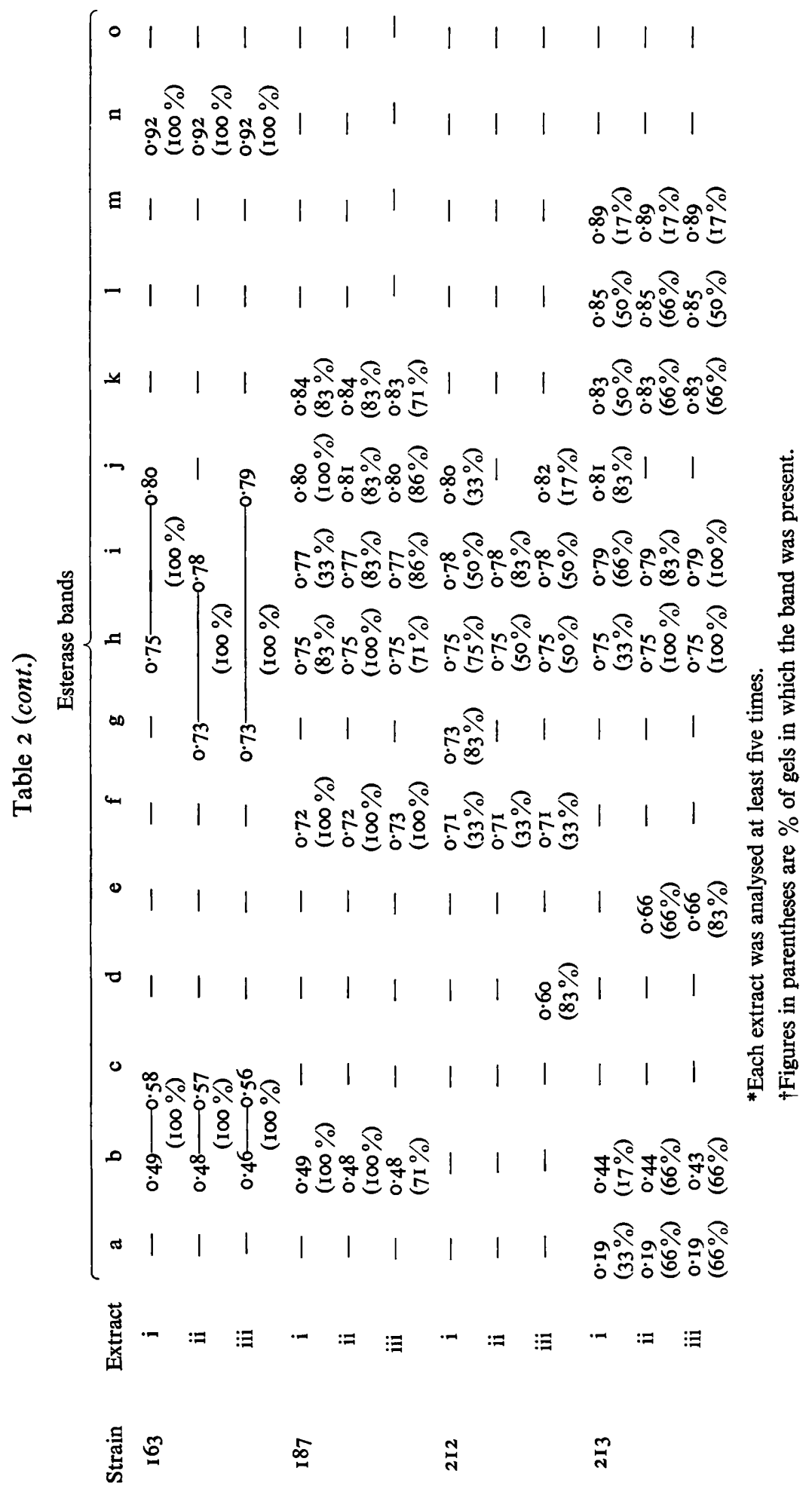


(a)

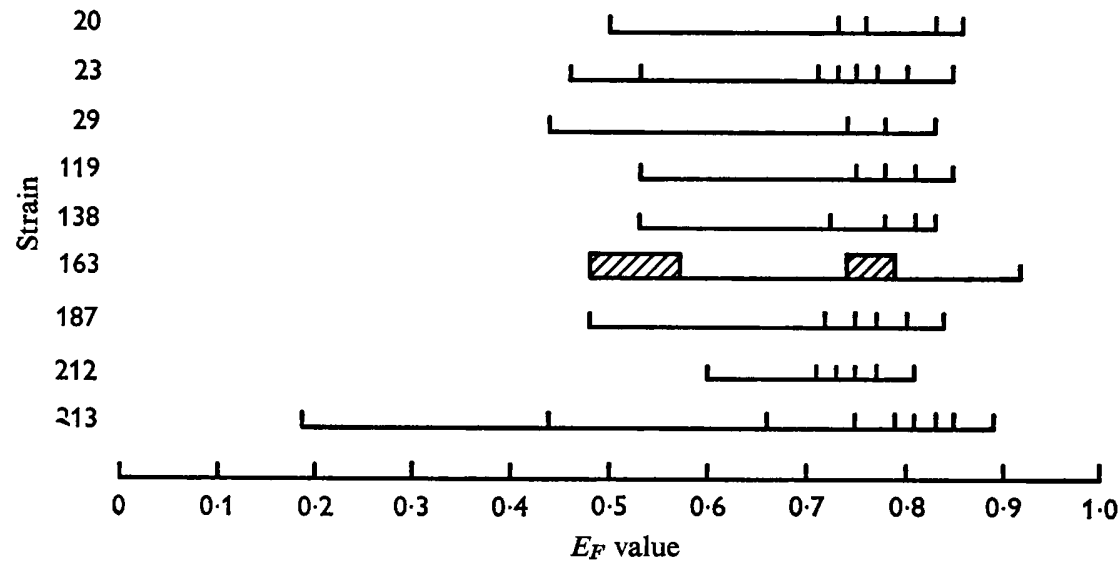

(b)

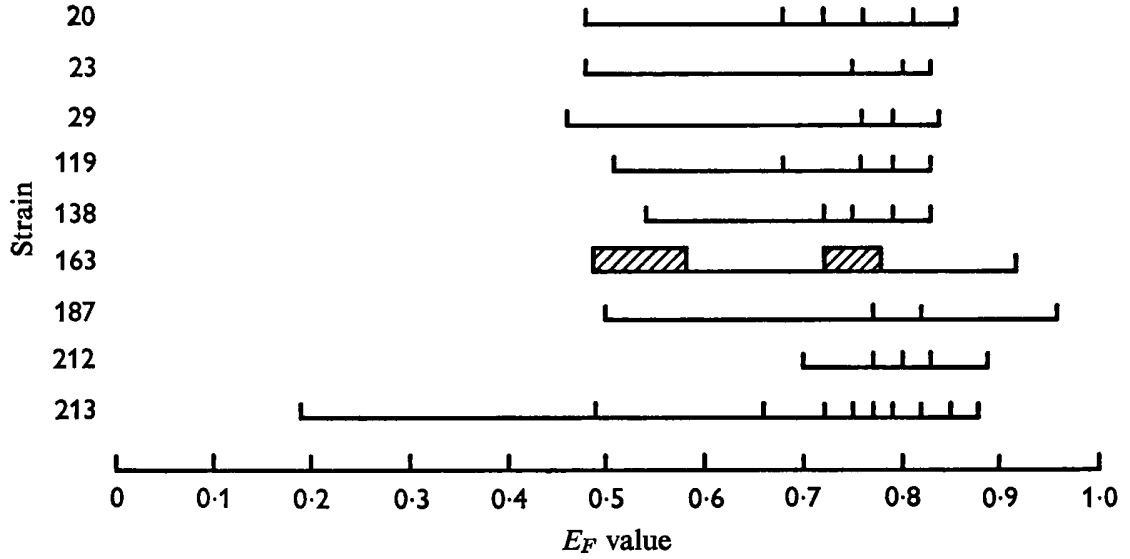

Fig. I. Esterase profiles of Mortierella ramanniana strains grown on (a) basal medium + glucose and $(b)$ basal medium +olive oil. The $E_{F}$ values given are the average values from all analyses of three cultures of each strain. The cross-hatched blocks refer to wide bands.

Table 3. Measurements of reproductive structures and giant cells of the Mortierella rammaniana strains examined. All measurements in microns

\begin{tabular}{|c|c|c|c|c|c|c|c|c|}
\hline \multirow[b]{2}{*}{ rain } & \multicolumn{2}{|c|}{$\begin{array}{c}\text { Sporangiophore } \\
\text { length }(\mu)\end{array}$} & \multicolumn{2}{|c|}{$\begin{array}{l}\text { Sporangium } \\
\text { diameter }(\mu)\end{array}$} & \multicolumn{2}{|r|}{ Spore size $(\mu)$} & \multicolumn{2}{|c|}{ Giant cells $(\mu)$} \\
\hline & Mean & Range & Mean & Range & Mean & Range & Mean & Range \\
\hline 20 & 46 & $150-625$ & $16 \cdot 9$ & 6 & $2 \cdot 4 \times I \cdot 8$ & ${ }^{\circ} 5$ & $\cdot 3$ & 28 \\
\hline 23 & & & & I 2 & & & & \\
\hline 29 & & 500 & & I5 & & & $5 \times 23 \cdot 0$ & $0 \times 1$ \\
\hline 119 & & 480 & & & & & - & - \\
\hline 138 & & & & & & & - & - \\
\hline 16 & & 180 & & & & 3.0 & - & - \\
\hline 187 & & & & & & & $1 \times 28 \cdot 2$ & \\
\hline 212 & & & & & & $2 \cdot 0-3$ & $\times 22.7$ & \\
\hline 213 & $4^{1}$ & $240-600$ & $16 \cdot 7$ & $10-28$ & $2.9 \times 2.4$ & $2 \cdot 0-4.0 \times 2.0-3.0$ & $9.7 \times 27.7$ & $\times 18$ \\
\hline
\end{tabular}


utilized during growth. At the start of the growth period the medium was opaque because of the emulsification of the oil with shaking. After 4 days the emulsion had been broken completely and the medium was clear. The fact that some components of the system produced only faint bands on the gels may reflect (i) that they were minor components of the multimolecular system, or (ii) that they were truly extracellular enzymes, in which case only small amounts would be expected in the mycelium, or (iii) that they were intracellular but not so active against the substrate used in these experiments. Of course if these esterases are intracellular they may still function in the break-down of extracellular lipids. It is generally believed that the older parts of fungal hyphae soon undergo autolysis and release their contents into the medium. Evidence relating to the criteria of Pollock (1962) is necessary before a definite statement on the nature of these enzymes may be given. Further studies on these systems are being made.

The variation in esterase profiles found between the different strains was surprising. Only strains 23 and 29 produced exactly the same pattern and then only when grown on olive-oil medium. If some of the assumptions mentioned earlier, relating to the location of certain bands, were made, then at least 4 strains $(20,23,29$, I I 9 ) would have basically the same pattern when grown on olive-oil medium. It has been stated that certain esterases are constant in all strains when grown on the 2 media. Whether the presence of these enzymes, when the fungi are grown under defined conditions, can be used as taxonomic criteria can only be assessed when other species of the genus are investigated.

Of the 9 strains examined, 20, 23, 212 and 213 are morphologically indistinguishable, and may be regarded as 'typical' Mortierella ramanniana. Strains II9 and I38 lack the large chlamydospores (' giant cells') which are normally found in these species. The sporangiophore of these two isolates, also those of 29 and 187 (both of which possess 'giant cells') are larger than those of the other strains; the spores of 138 and I 87 are slightly larger and more oval; those of 29 are larger still and definitely elliptical. Since the columella is also unusually well developed, and the colony colour slightly different, this isolate 29 may represent a variety of the species (Turner, I963), but the esterase pattern provides no further evidence for this. In fact for these 8 strains there seems to be little or no correlation between the variations in the esterase pattern and the morphological differences.

The only strain which shows any marked morphological differences, and which also shows a markedly different esterase pattern is strain I63. This strain, in addition to the normal type of sporangiophore (rather shorter than usual but still well within the range of variation for the species), produces in parts of the colony a number of very short sporangiophores $(30-60 \mu$ long), unbranched or branching in a manner resembling Mortierella vinacea. It also resembles this species in being thiazole-independent, and in lacking the 'giant cells' of M. ramanniana. However, the characteristically angular spores of $M$. vinacea have not been seen with this isolate I63. This was at first suspected of being a mixed culture, but repeated re-isolations from single spores or hyphal tips continue to present the same picture. According to Dr E. A. Evans (personal communication) such strains are not uncommon, and they can mutate spontaneously to produce normal, thiazole-dependent $M$. ramanniana strains. The difference in esterase pattern may be of significance here. Comparison with other similar isolates and with typical strains of $M$. vinacea, should prove interesting. 
We wish to thank Dr M. Moore for doing vertical starch-gel electrophoresis on strain I63, Mr D. J. Allen for technical help and Mr T. Burke for photography.

\section{REFERENCES}

Aranson, A. \& Pantelouris, E. M. (1966). Serum esterases of Apodemus sylvaticus and Mus musculus. Comp. Biochem. Physiol. 19, 53.

BAILlIE, A. \& Norris, J. R. (1963). Studies of enzyme changes during sporulation in Bacillus cereus, using starch gel electrophoresis. J. appl. Bact. 26, 102.

CANN, D. C. \& WILlox, M. E. (1965). Analysis of multimolecular enzymes as an aid to the identification of certain rapidly growing Mycobacteria, using starch gel electrophoresis. J. appl. Bact. 28, 165.

Chang, L. O., SRb, A. M. \& Steward, F. C. (1962). Electrophoretic separation of the soluble proteins of Neurospora. Nature, Lond. 193, 756.

Chesters, C. G. C. \& Peberdy, J. F. (1965). Nutritional factors in relation to growth and fat synthesis in Mortierella vinacea. J. gen. Microbiol. 4r, 127.

Clare, B. G. (1963). Starch gel electrophoresis of proteins as an aid in identifying fungi. Nature, Lond. 200, 803.

DURBIN, R. D. (1966). Comparative gel electrophoretic investigation of protein patterns of Septoria species. Nature, Lond. 210, 1186.

GotTLiEB, D. \& HePDEN, P. M. (1966). The electrophoretic movement of proteins from various Streptomyces species as a taxonomic criterion. J. gen. Microbiol. 44, 95.

Lawrence, S. H., Melnick, P. J. \& Weimer, H. E. (I960). A species comparison of serum proteins and enzymes by starch gel electrophoresis. Proc. Soc. exp. Biol. Med. 105, 572.

NorRIs, J. R. (1964). Classification of Bacillus thuringiensis. J. appl. Bact. 27, 439.

Pollock, M. R. (1962). Exoenzymes. In The Bacteria. Ed. by I. C. Gunsalus and R. Y. Stanier, vol. 4, p. 121. New York and London: Academic Press.

Poulik, M. D. (1957). Starch gel electrophoresis in a discontinuous system of buffers. Nature, Lond. I80, 1477 .

RoBrnson, K. (1966). An examination of Corynebacterium spp. by gel electrophoresis. J. appl. Bact. 29, 179.

SMIrHIEs, O. (1955). Zone electrophoresis in starch gels: group variations in the serum proteins of normal human adults. Biochem. J. 6r, 629.

TURNER, M. (1963). Studies in the genus Mortierella I. Mortierella isabellina, and related species. Trans. Br. Mvcol. Soc. 46. 262 